\title{
PENGARUH FAKTOR SOSIAL EKONOMI TERHADAP KEMISKINAN DI PROVINSI JAWA BARAT
}

(The Effect of Socio-Economic Factor on Poverty Level in West Java Province)

\author{
Dwi Ardian', Muhammad Rizqi Destanto² \\ Badan Pusat Statistik Kabupaten Mamasa, Provinsi Sulawesi Barat ${ }^{1}$ \\ Mahasiswa Diploma IV Politeknik Statistika STIS Angkatan ke-58 ${ }^{2}$ \\ Kantor BPS Kabupaten Mamasa, Jl. Poros Banggo Desa Osango Mamasa, 91362 \\ E-mail: dwi.ardian@bps.go.id
}

\begin{abstract}
ABSTRAK
Kemiskinan masih menjadi permasalahan besar di negara sedang berkembang seperti Indonesia. Salah satu daerah yang memiliki sumbangsih cukup besar terhadap kemiskinan di Indonesia adalah Provinsi Jawa Barat. Jawa Barat menempati urutan ketiga dengan penduduk termiskin terbanyak di Indonesia dengan sumbangsih mencapai 13,79 persen, hanya di bawah Jawa Timur dan Jawa Tengah. Kemiskinan adalah masalah kompleks yang butuh perhatian lebih terhadap penanganannya. Diperlukan suatu kajian yang cukup mendalam untuk mengetahui apa saja yang harus menjadi prioritas dalam mengatasi kemiskinan. Penelitian ini mengkaji variabel dari faktor sosial ekonomi apa saja yang memengaruhi kemiskinan di Provinsi Jawa Barat. Data yang digunakan adalah data panel tahun 20142018 yang telah dirilis oleh Badan Pusat Statistik (BPS) Provinsi dan kabupaten/kota se-Jawa Barat serta data lain dari Kemenkeu. Metode yang digunakan yakni regresi data panel terhadap variabel yang diduga memiliki pengaruh terhadap kemiskinan berdasarkan teori-teori para ahli. Hasil yang diperoleh adalah pertumbuhan ekonomi, tingkat pengangguran terbuka (TPT), dana alokasi umum (DAU), dan kepadatan penduduk tidak memiliki pengaruh yang signifikan terhadap kemiskinan di Jawa Barat. Variabel indeks pembangunan manusia (IPM) yang disusun atas rata-rata lama sekolah, harapan lama sekolah, usia harapan hidup, dan pendapatan per kapita memiliki pengaruh yang signifikan terhadap kemiskinan. Jadi, langkah-langkah yang harus diambil oleh pemilik kebijakan adalah memastikan kesehatan masyarakat terjamin dengan penyediaan fasilitas yang cukup dan memadai, menyediakan sarana pendidikan termasuk pendidik yang tidak hanya cukup dari sisi kuantitas tetapi juga memiliki kualitas tinggi. Upaya lain adalah memastikan stabilitas harga dan menjaga daya beli masyarakat dengan pendapatan yang cukup serta harga kebutuhan yang terjangkau.
\end{abstract}

Kata kunci: kemiskinan, IPM, TPT, pertumbuhan ekonomi, DAU, regresi data panel

\section{ABSTRACT}

Poverty is still a major problem in developing countries like Indonesia. One province that has contributed to the poverty of Indonesia is the Province of West Java. West Java is the third poorest population in indonesia, contributing to 13.79 percent, just under East Java and Central Java. Poverty is a complex problem that needs more attention to its treatment. It takes an in-depth study to determine what must take priority in dealing with poverty. This study tries to identify the socio-economic factor to affecting poverty in the Province of West Java. The data used is by the 2014-2018 panel data released by the Central Statistics Office of Indonesia (BPS) province of West Java and other available data from Ministry of Finance Indonesia (Kemenkeu). The method used in this study is panel data regressions into the presumed variables are affecting poverty based on expert theories. The results have been economic growth, the open unemployment rate (TPT), the public allocation fund (DAU), and the population density has no significant impact on poverty in West Java. The human development index variable (HDI), compiled for school average, school-time hopes, life expectancy, and per capita income, has a significant impact on poverty. So the step that government must take are to ensure public health with adequate facilities, providing educational facilities including teachers who not only have enough from the quantity side but also have high quality. Another attempt is to ensure stability at prices and maintain purchasing power of society with adequate income and affordable price of needs.

Keywords: poverty, HDI, TPT, economic growth, DAU, panel data regression 


\section{PENDAHULUAN}

Kemiskinan adalah kondisi penduduk tidak bisa terpenuhi kebutuhan dasarnya (basic needs approach) (BPS, 2018). BPS mengukur kondisi kemiskinan berdasarkan garis kemiskinan (GK). GK diperoleh dari penjumlahan garis kemiskinan makanan (GKM) dan garis kemiskinan nonmakanan (GKNM). Penduduk yang berada di bawah GK kemudian disebut sebagai penduduk miskin. Persentase penduduk miskin terhadap jumlah seluruh penduduk disebut tingkat kemiskinan.

Kemiskinan merupakan masalah serius bagi setiap negara, termasuk di Indonesia. Kemiskinan dipengaruhi oleh banyak faktor di antaranya produktivitas untuk bekerja, pertumbuhan ekonomi, pendapatan per kapita, ketimpangan pendapatan, fasilitas dan pelayanan kesehatan, gizi dan wabah penyakit, tingkat kematian bayi, serta fasilitas pendidikan dan kurikulum yang kurang relevan (Todaro \& Smith, 2003).

Telah banyak program yang dianggap prorakyat oleh pemerintah. Di antara program tersebut adalah penyediaan kebutuhan dasar seperti pangan, pelayanan kesehatan dan pendidikan, perluasan kesempatan kerja, pembangunan dalam bidang pertanian, pemberian dana bergulir melalui sistem kredit, pembangunan prasarana dan pendampingan, sanitasi, serta program lainnya. Belum lagi berbagai program subsidi bagi masyarakat tidak mampu telah dilakukan. Semua itu untuk dilakukan agar diperoleh target penurunan kemiskinan yang sesuai harapan (Azwar \& Subekan, 2016).

Dalam Rancangan Pembangunan Jangka Menengah (RPJMD) Jawa Barat tahun 2013-2018, pemerintah menargetkan angka kemiskinan mengalami penurunan mencapai sekitar 4,1-5 persen pada tahun 2018. Target tersebut relatif jauh meleset dari kenyataan bahwa tingkat kemiskinan pada tahun 2018 masih berada di angka 7,25 persen menurut data BPS. Penurunan kemiskinan sendiri telah terjadi di beberapa tahun terakhir, meskipun penurunan sangat lambat. Anggaran yang digelontorkan dianggap tidak sebanding dengan penurunan di bawah 1 persen per tahun.

Jawa Barat sebagai salah satu provinsi terbesar di Indonesia termasuk yang menjadi sorotan. Jika dilihat dari persentase kemiskinan Jawa Barat pada tahun 2018 sebesar 7,25 persen. Artinya, masih di bawah tingkat kemiskinan nasional. Sayangnya, angka itu masih menjadi catatan besar karena kontribusinya terhadap tingkat kemiskinan nasional ternyata sangat besar. Kontribusinya mencapai 13,79 persen atau berada di peringkat ke-3 setelah Jawa Timur (16,72 persen) dan Jawa Tengah dengan kontribusi 15,06 persen (BPS, 2018).

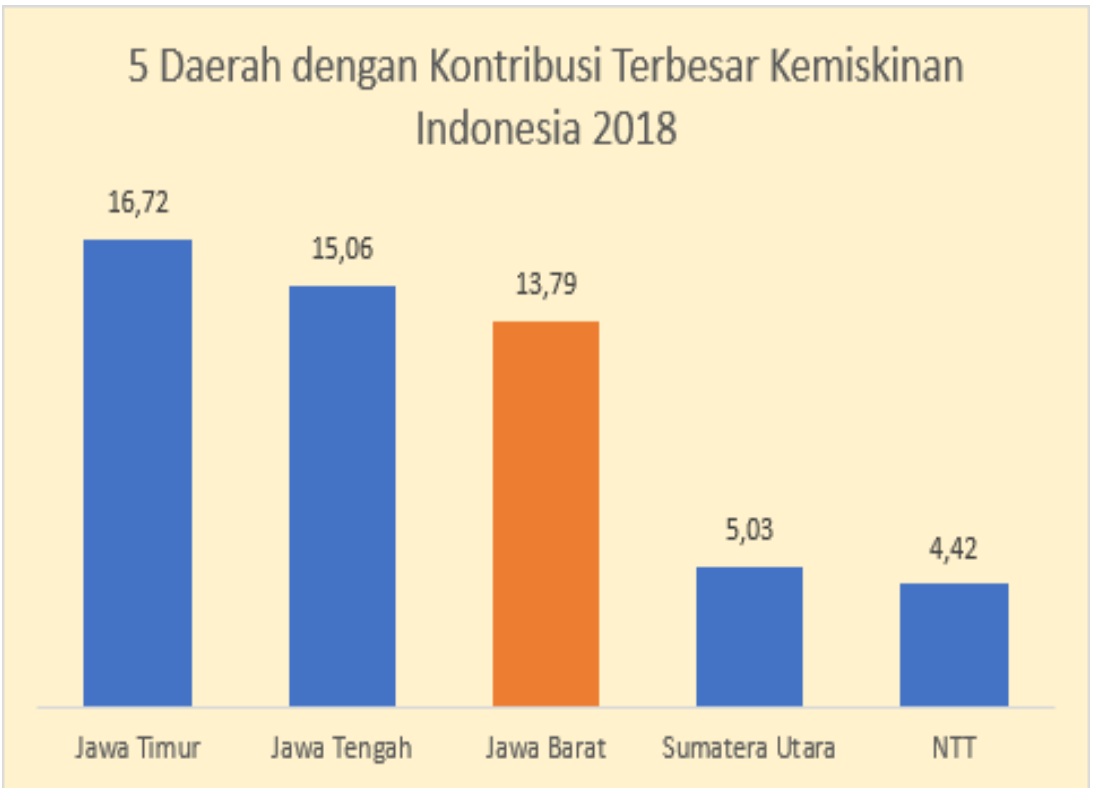

Gambar 41. Lima daerah dengan kontribusi terbesar terhadap kemiskinan Indonesia, Tahun 2018 (persen). 
Dari sisi ketimpangan, Jawa Barat juga tercatat menjadi provinsi dengan rasio gini terbesar ketiga $(0,405)$, hanya di bawah gini rasio DIY $(0,422)$ dan Gorontalo $(0,417)$. Padahal, target pemerintah dalam RPJMD Jawa Barat 2013-2018 rasio gini bisa mencapai 0,33-0,34 poin pada akhir tahun 2018. Jika dilihat dari perbandingan antara perkotaan dan perdesaan, juga terjadi ketimpangan tingkat kemiskinan. Di perkotaan 6,33 persen sedangkan perdesaan mencapai 10,07 persen (BPS, 2018).

\section{Daerah dengan Rasio Gini Tertinggi}

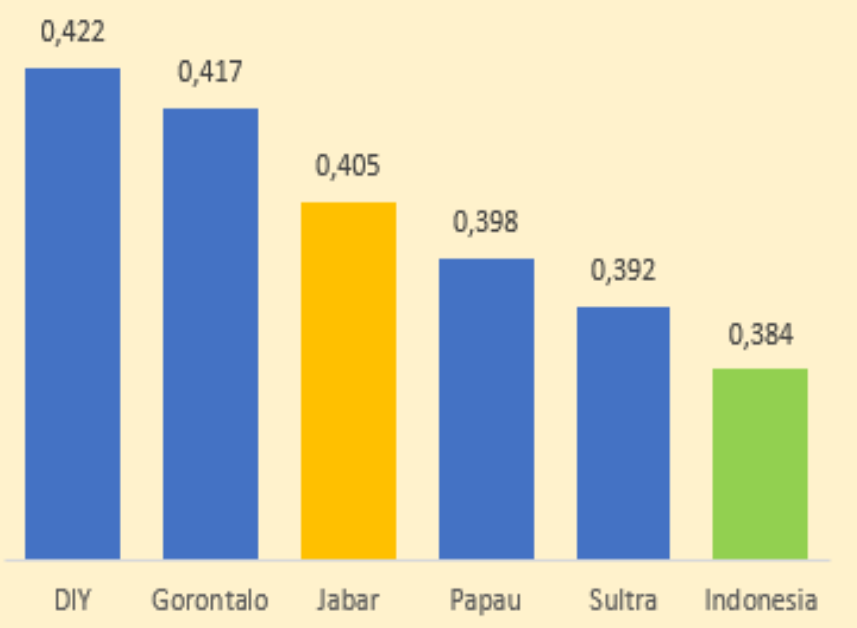

Gambar 2. Lima daerah dengan rasio gini tertinggi, Tahun 2018.

\section{METODE}

\section{Metode Pengumpulan Data}

Penelitian ini dilakukan menggunakan 27 kabupaten/kota yang ada di Jawa Barat. Jumlah tahun yang diamati adalah 5 yakni dari tahun 2014 sampai tahun 2018. Pendekatan dalam penelitian ini adalah pendekatan kuantitatif dengan data yang bersumber dari BPS dan Kemenkeu terbaru. Teknik pengumpulan data adalah dengan cara mengkompilasi data yang bersumber dari publikasi dan berita resmi statistik hasil dari Survei Sosial Ekonomi Nasional (Susenas), Survei Angkatan Kerja Nasional (Sakernas), data DAU Kemenkeu, dan data lain yang terkait untuk tahun 2014-2018.

\section{Metode Analisis Data}

Metode analisis yang digunakan dalam penelitian ini adalah terdiri dari dua metode, yaitu analisis deskriptif dan analisis inferensia. Analisis deskriptif melalui penyajian data dalam bentuk tabel, gambar, dan diagram, sedangkan analisis inferensia yang digunakan dalam penelitian ini adalah analisis regresi data panel.

Variabel yang dianalisis dalam regresi data panel ini berupa variabel terikat (dependent variable) adalah tingkat kemiskinan dan variabel bebas (independent variables) adalah pertumbuhan ekonomi, TPT, IPM, DAU, dan kepadatan penduduk. Model regresi data panel secara umum berbentuk:

$Y_{i t}=\alpha+\beta_{1} X_{i t}+\beta_{2} X_{i t}+\beta_{3} X_{i t}+\beta_{4} X_{i t}+\beta_{5} X_{i t}+\varepsilon_{i t}(1)$

di mana:

$Y_{\text {it }}$ : variabel dependen, dalam hal ini tingkat kemiskian Jawa Barat

$\alpha$ : intersep

$\beta$ : slope atau kemiringan garis regresi

$X_{i t}$ : variabel independent yang terdiri atas 5 variabel dengan waktu 5 tahun

$\varepsilon \quad$ : eror dan atau variabel yang belum masuk model 
Tabel 2. Deskripsi variabel independen dan ekspektasi pengaruh terhadap variabel dependen.

\begin{tabular}{|c|c|c|c|}
\hline Variabel & Simbol & Deskripsi & $\begin{array}{l}\text { Ekspektasi } \\
\text { Pengaruh }\end{array}$ \\
\hline $\begin{array}{l}\text { Tingkat } \\
\text { Kemiskinan }\end{array}$ & $\bar{Y}$ & $\begin{array}{l}\text { Tingkat kemiskinan merupakan persentase } \\
\text { penduduk miskin terhadap jumlah penduduk } \\
\text { keseluruhan di tiap kabupaten/kota. } \\
\text { Penduduk miskin adalah penduduk yang } \\
\text { konsumsinya di bawah garis kemiskinan } \\
\text { (GK). Satuannya berupa persentase. }\end{array}$ & \\
\hline $\begin{array}{l}\text { Pertumbuhan } \\
\text { ekonomi }\end{array}$ & $X_{1}$ & $\begin{array}{l}\text { Pertumbuhan ekonomi merupakan proses } \\
\text { kenaikan kapasitas produksi suatu } \\
\text { perekonomian yakni kenaikan produk } \\
\text { domestik bruto (PDB//PDRB) antar-periode } \\
\text { tertentu. Satuannya berupa persen. }\end{array}$ & $(-)$ \\
\hline $\begin{array}{l}\text { Indeks } \\
\text { pembangunan } \\
\text { manusia } \\
\text { (IPM) }\end{array}$ & $x_{2}$ & $\begin{array}{l}\text { IPM disusun atas tiga dimensi menurut } \\
\text { penghitungan terbaru BPS, yaitu indeks } \\
\text { kesehatan diukur dari UHH, indeks } \\
\text { pendidikan diukur dari HLS dan RLS, serta } \\
\text { indeks standar hidup layak yang diukur dari } \\
\text { daya beli (pengeluaran) per kapita. } \\
\text { Satuannya berupa poin indeks 1-100. }\end{array}$ & $(-)$ \\
\hline $\begin{array}{l}\text { Tingkat } \\
\text { pengangguran } \\
\text { terbuka (TPT) }\end{array}$ & $x_{3}$ & $\begin{array}{l}\text { TPT merupakan persentase jumlah } \\
\text { pengangguran terbuka terhadap jumlah } \\
\text { angkatan kerja di tiap kabupaten/kota. } \\
\text { Satuannya berupa persentase. }\end{array}$ & $(+)$ \\
\hline $\begin{array}{l}\text { Dana Alokasi } \\
\text { Umum (DAU) }\end{array}$ & $X_{4}$ & $\begin{array}{l}\text { DAU adalah sejumlah dana yang harus } \\
\text { dialokasikan Pemerintah Pusat kepada setiap } \\
\text { Daerah Otonom (provinsi/kabupaten/kota) di } \\
\text { Indonesia setiap tahunnya sebagai dana } \\
\text { pembangunan. DAU merupakan salah satu } \\
\text { komponen belanja pada APBN, dan menjadi } \\
\text { salah satu komponen pendapatan pada } \\
\text { APBD. Satuannya berupa miliar rupiah } \\
\text { (Rp000.000.000). }\end{array}$ & $(-)$ \\
\hline $\begin{array}{l}\text { Kepadatan } \\
\text { Penduduk }\end{array}$ & $X_{5}$ & $\begin{array}{l}\text { Kepadatan penduduk merupakan } \\
\text { perbandingan antara jumlah penduduk } \\
\text { (jiwa) terhadap luas kabupaten/kota. } \\
\text { Kepadatan penduduk biasanya satuannya } \\
\text { adalah jiwa per } \mathrm{km}^{2} \text {. }\end{array}$ & $(+)$ \\
\hline
\end{tabular}

\section{Pengujian Pemilihan Model}

Langkah-langkah dalam pengujian pemilihan model adalah sebagai berikut:

1. Estimasi dengan Fixed Effect: memasukkan efek individu dan dan waktu. Yang sangat memengaruhi variabel terikat adalah slope dan intercept.

2. Uji Chow: untuk menentukan model yang digunakan apakah common effect atau fixed effect. Jika HO gagal tolak (prob cross section $\mathrm{F}$ dan Chi Square > 0,05), maka yang dipilih adalah Common Effect. Jika HO ditolak (prob cross section F dan Chi Square < 0,05), maka yang dipilih Fixed Effect.

3. Estimasi dengan Random Effect: Memasukkan efek dimensi individu dan waktu, di mana efek tersebut terletak pada eror dari model.

4. Uji Hausman: menentukan model yang digunakan apakah fixed atau random effect. Jika $\mathrm{HO}$ gagal tolak (nilai prob cross section random $>0,05$ ), maka dipilih random effect. Jika HO ditolak (nilai prob cross section random $<0,05$ ), maka dipilih model fixed effect. 
5. Uji Lagrange Multiplier: merupakan uji untuk mengetahui apakah model random effect lebih baik daripada metode common effect digunakan. Jika $\mathrm{HO}$ gagal tolak (nilai prob cross section random $>0,05$ ), maka dipilih common effect. Jika HO ditolak (nilai prob cross section random $<0,05$ ), maka dipilih model random effect. Apabila yang dipilih adalah random effect maka estimasi memakai asumsi generelized least square (GLS).

\section{HASIL DAN PEMBAHASAN}

Tingkat kemiskinan di Indonesia dihitung oleh BPS dengan pendekatan pengeluaran atau konsumsi minimal yang harus dipenuhi oleh penduduk. Kemiskinan adalah ketidakmampuan dari sisi ekonomi untuk memenuhi kebutuhan dasar makanan dan bukan makanan yang diukur dari sisi pengeluaran (BPS, 2019).

Garis kemiskinan adalah penjumlahan dari Garis Kemiskinan Makanan (GKM) dan Garis Kemiskinan Non-Makanan (GKNM). GKM merupakan nilai pengeluaran kebutuhan minimum makanan yang disetarakan dengan 2.100 kilo kalori per kapita per hari. Paket komoditas kebutuhan dasar makanan diwakili oleh 52 jenis komoditas (padi-padian, umbi-umbian, ikan, daging, telur dan susu, sayuran, kacang-kacangan, buah-buahan, minyak dan lemak, dll.). GKNM adalah kebutuhan minimum untuk perumahan, sandang, pendidikan, dan kesehatan. Paket komoditas kebutuhan non-makanan diwakili oleh 51 jenis komoditas di perkotaan dan 47 jenis komoditas di perdesaan.

Jika ditilik dari tingkat kemiskinan, variasi tingkat kemiskinan provinsi di Indonesia sangat besar. Ada yang tingkat kemiskinannya kecil seperti Daerah Istimewa Yogyakarta (DIY) dan DKI Jakarta, ada pula yang tingkat kemiskinannya sangat besar seperti Papua dan Papua Barat. Tingkat kemiskinan tidak selalu berbanding lurus dengan jumlah orang miskin atau kontribusi kemiskinan terhadap total penduduk Indonesia. Bisa saja tingkat kemiskinan kecil tetapi kontribusi jumlah kemiskinannya besar. Tingkat kemiskinan Indonesia pada tahun 2018 mencapai 9,66 persen.

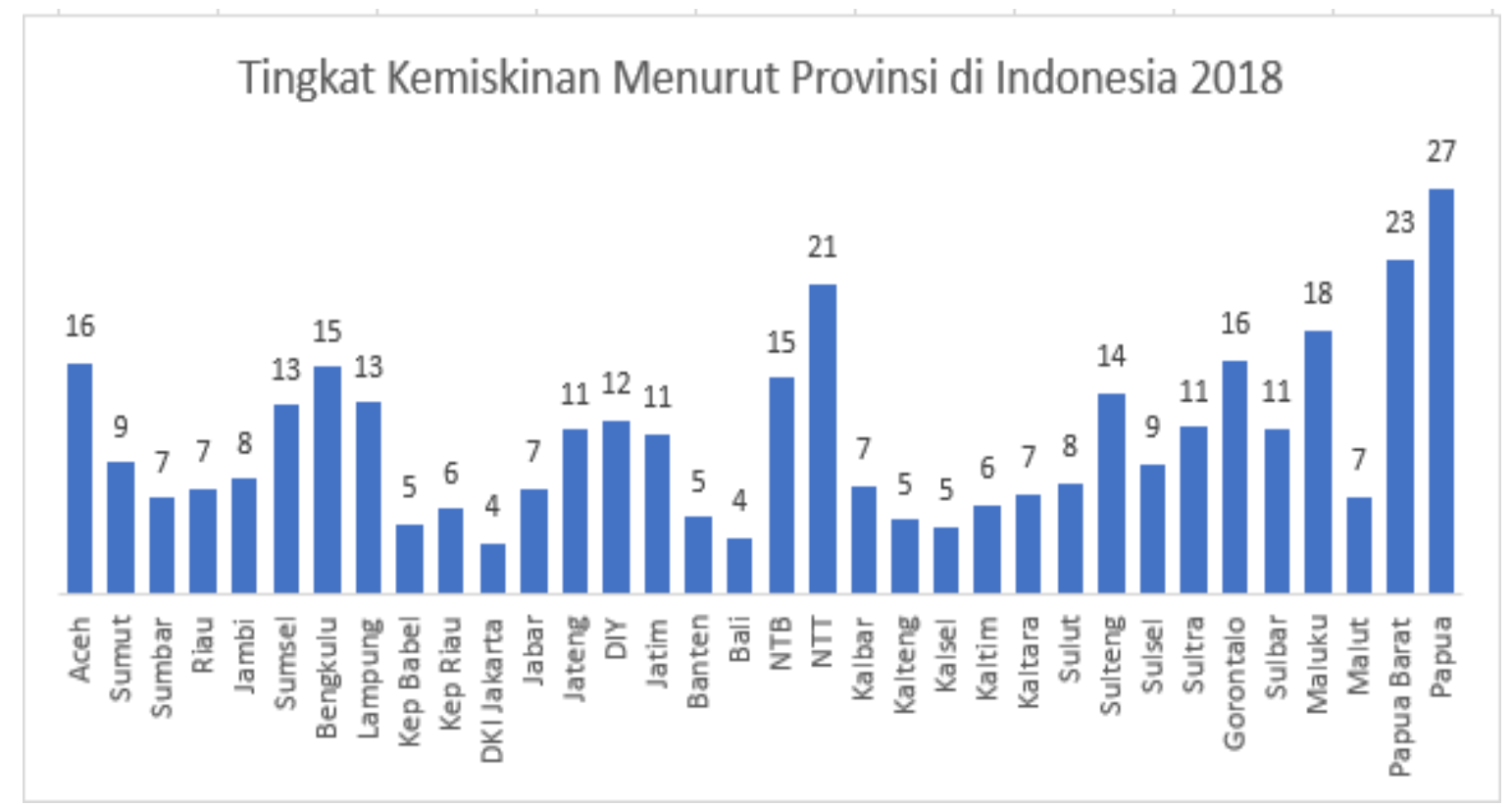

Gambar 3. Tingkat kemiskinan 34 provinsi di Indonesia, Tahun 2018 (persen).

Tingkat kemiskinan Jawa Barat pada tahun 2018 mencapai 7,25 persen. Angka yang sebenarnya di bawah tingkat kemiskinan nasional. Namun, dari sisi jumlah masih sangat besar, apalagi kalau kita perhatikan ada ketimpangan yang cukup besar. Berikut adalah data kemiskinan kabupaten/kota di Jawa Barat. 
Tabel 2. Tingkat kemiskinan kabupaten/kota di Provinsi Jawa Barat, tahun 2014-2018.

\begin{tabular}{|c|c|c|c|c|c|c|}
\hline \multirow{2}{*}{ No } & \multirow{2}{*}{ Kabupaten/Kota } & \multicolumn{5}{|c|}{ Tingkat Kemiskinan (persen) } \\
\hline & & 2014 & 2015 & 2016 & 2017 & 2018 \\
\hline 1 & Bogor & 8,91 & 8,96 & 8,83 & 8,57 & 7,14 \\
\hline 2 & Sukabumi & 8,81 & 8,96 & 8,13 & 8,04 & 6,76 \\
\hline 3 & Cianjur & 11,47 & 12,21 & 11,62 & 11,41 & 9,81 \\
\hline 4 & Bandung & 7,65 & 8,00 & 7,61 & 7,36 & 6,65 \\
\hline 5 & Garut & 12,47 & 12,81 & 11,64 & 11,27 & 9,27 \\
\hline 6 & Tasikmalaya & 11,26 & 11,99 & 11,24 & 10,84 & 9,85 \\
\hline 7 & Ciamis & 8,38 & 8,98 & 8,42 & 8,2 & 7,22 \\
\hline 8 & Kuningan & 12,72 & 13,97 & 13,59 & 13,27 & 12,22 \\
\hline 9 & Cirebon & 14,22 & 14,77 & 13,49 & 12,97 & 10,70 \\
\hline 10 & Majalengka & 13,42 & 14,19 & 12,85 & 12,6 & 10,79 \\
\hline 11 & Sumedang & 10,78 & 11,36 & 10,57 & 10,53 & 9,76 \\
\hline 12 & Indramayu & 14,29 & 14,98 & 13,95 & 13,67 & 11,89 \\
\hline 13 & Subang & 11,73 & 12,27 & 11,05 & 10,77 & 8,67 \\
\hline 14 & Purwakarta & 8,80 & 9,14 & 8,98 & 9,06 & 7,99 \\
\hline 15 & Karawang & 10,15 & 10,37 & 10,07 & 10,25 & 8,06 \\
\hline 16 & Bekasi & 4,97 & 5,27 & 4,92 & 4,73 & 4,37 \\
\hline 17 & Bandung Barat & 12,26 & 12,67 & 11,71 & 11,49 & 10,06 \\
\hline 18 & Pangandaran & 10,89 & 10,76 & 10,23 & 10 & 8,12 \\
\hline 19 & Kota Bogor & 7,74 & 7,60 & 7,29 & 7,11 & 5,93 \\
\hline 20 & Kota Sukabumi & 7,65 & 8,79 & 8,59 & 8,48 & 7,12 \\
\hline 21 & Kota Bandung & 4,65 & 4,61 & 4,32 & 4,17 & 3,57 \\
\hline 22 & Kota Cirebon & 10,03 & 10,36 & 9,73 & 9,66 & 8,88 \\
\hline 23 & Kota Bekasi & 5,25 & 5,46 & 5,06 & 4,79 & 4,11 \\
\hline 24 & Kota Depok & 2,32 & 2,40 & 2,34 & 2,34 & 2,14 \\
\hline 25 & Kota Cimahi & 5,47 & 5,84 & 5,92 & 5,76 & 4,94 \\
\hline 26 & Kota Tasikmalaya & 15,95 & 16,28 & 15,60 & 14,8 & 12,71 \\
\hline 27 & Kota Banjar & 6,95 & 7,41 & 7,01 & 7,06 & 5,70 \\
\hline
\end{tabular}

Sumber: jabar.bps.go.id

Langkah-langkah dalam pengujian pemilihan model adalah sebagai berikut:

\section{Estimasi dengan Fixed Effect}

Memasukkan efek individu dan dan waktu. Yang sangat memengaruhi variabel terikat adalah slope dan intercept.

\section{Uji Chow}

Berdasarkan pengolahan data diperoleh prob cross section F dan Chi Square 0,0000<0,05, berarti $\mathrm{H}_{0}$ ditolak atau yang dipilih Fixed Effect.

\section{Estimasi dengan Random Effect}

Memasukkan efek dimensi individu dan waktu, di mana efek tersebut terletak pada eror dari model.

\section{Uji Hausman}

Berdasarkan hasil pengolahan data diperoleh nilai prob cross section random $0,6284>0,05$, berarti gagal tolak atau yang kita pilih adalah random effect.

\section{Uji Lagrange Multiplier}

Untuk mengetahui apakah model random effect lebih baik daripada metode common effect digunakan. Berdasarkan hasil pengolahan diperoleh nilai prob cross section random 
0,0000<0,05 pada Breusch-Pagan, yang berarti kita memilih model terbaik adalah random effect.

\begin{tabular}{crrrr}
\hline \hline Variable & Coefficient & Std. Error & t-Statistic & Prob. \\
\hline \hline C & 57.74037 & 4.107782 & 14.05634 & 0.0000 \\
DAU & -0.000386 & 0.000272 & -1.417088 & 0.1589 \\
TPT & -0.019951 & 0.050756 & -0.393083 & 0.6949 \\
IPM & -0.690240 & 0.058619 & -11.77510 & 0.0000 \\
EKONOMI & -0.062513 & 0.082503 & -0.757699 & 0.4500 \\
KEPADATAN & 0.000153 & $9.99 E-05$ & 1.530368 & 0.1284 \\
\hline \hline
\end{tabular}

Gambar 4. Output hasil pengolahan estimasi random effect (model terpilih).

Berdasarkan Gambar 4 diperoleh kesimpulan bahwa IPM memiliki pengaruh yang signifikan terhadap kemiskinan di Jawa Barat.

\section{KESIMPULAN}

Variabel pertumbuhan ekonomi sesuai ekspektasi di awal bahwa akan memiliki pengaruh negatif terhadap tingkat kemiskinan, benar adanya. Akan tetapi, pengaruhnya terhadap tingkat kemiskinan di Jawa Barat tidak signifikan. Hal ini sesuai dengan penelitian yang dilakukan oleh Azwar dan Subekan (2017). Hasil ini juga mengindikasikan bahwa pertumbuhan ekonomi di Jawa Barat belum menyentuh secara menyeluruh terhadap masyarakat menengah ke bawah. Kalau dilihat dari asal pertumbuhan yang masih didominasi oleh sektor real estate maka hal itu menggambarkan bahwa pertumbuhan ekonomi belum benar-benar pro terhadap masyarakat kalangan bawah.

Variabel IPM memiliki pengaruh negatif dan sangat signifikan terhadap tingkat kemiskinan di Jawa Barat. Hal ini sesuai dengan ekspektasi di awal dan sesuai pula dengan penelitian Zuhdiyaty dan David (2017), Nisywaty (2014), dan lain-lain. Variabel TPT tidak memiliki pengaruh terhadap tingkat kemiskinan di jawa Barat. Variabel DAU memiliki pengaruh negatif tetapi tidak signifikan terhadap tingkat kemiskinan di Jawa Barat. Variabel kepadatan penduduk memiliki pengaruh positif tetapi tidak signifikan terhadap tingkat kemiskinan di Jawa Barat.

\section{DAFTAR PUSTAKA}

\section{Artikel dalam Jurnal (Jurnal Primer)}

Azwar, \& Subekan, A. (2016). Determinant Analysis of Poverty in South Sulawesi. Jurnal Badan Pendidikan dan Pelatihan Keuangan, Indonesia, 1-26.

Fauzi, F., Didu, S. (2016). Pengaruh Jumlah Penduduk, Pendidikan, dan Pertumbuhan Ekonomi terhadap Kemiskinan di Kabupaten Lebak. Jurnal Jurnal Ekonomi-Cu, Indonesia, 100-114.

Jolianis (2016). Analisis Pengaruh PAD, DAU dan DAK terhadap Kemiskinan pada Kabupaen/Kota di Provinsi Sumatera Barat dengan Pertumbuhan Ekonomi sebagai Variabel Intervening.Jurnal of Economic and Economic Education, Indonesia, 192-209.

Mahsunah, D. (2014). Analisis Pengaruh Jumlah Penduduk, Pendidikan, dan Pengangguran terhadap Kemiskinan di Jawa Timur. Jurnal Pendidikan Ekonomi Unesa, Indonesia, 1-17.

Niswati, K. (2014). Faktor-Faktor yang Mempengaruhi Kemiskinan di Daerah Istimewa Yogyakarta Tahun 2003 - 2011. Jurnal Eko Regional, 81-89.

Nopriansyah, Junaidi, \& Umiyati, E. (2015). Determinan Kemiskinan Rumah Tangga di Provinsi Jambi. Jurnal Perspektif Pembiayaan dan Pembangunan Daerah, 119-129.

Roostartina, E. (2013). Analisis Sosial dan Ekonomi Kemiskinan di Kelurahan Sungai Lilin Kecamatan Sungai Lilin Kabupaten Musi Banyuasin. Jurnal Ekonomi Pembangunan, 20-33.

Sunusi, D., Kumenaung, A., \& Rotinsulu, D. (2014). Analisis Pengaruh Jumlah Tenaga Kerja, Tingkat Pendidikan, Pengeluaran Pemerintah pada Pertumbuhan Ekonomi dan Dampaknya Terhadap Kemiskinan di Sulawesi Utara Tahun 2001 - 2010. Jurnal Berkala IImiah Efisiensi, 120-138.

Usman, Sinaga, B., \& Siregar, H. (2004). Analisis Determinan Kemiskinan Sebelum dan Sesudah Desentralisasi Fiskal. 1-17.

Wahyuni, R., \& Damayanti, A. (2014). Faktor-Faktor yang Menyebabkan Kemiskinan di Provinsi Papua: Analisis Spatial Heterogenity. Jurnal Ekonomi dan Pembangunan Indonesia Vol. 14, 128-144. 
Zamhari, J., Wisadirana, D., \& Kantor, S. (2015). Analisis Determinan Kemiskinan di Jawa Timur. Jurnal Wacana, 41-50.

Zuhdiyati, N. (2017). Analisis Faktor-Faktor yang Mempengaruhi Kemiskinan di Indonesia Selama Lima Tahun Terakhir (Studi Kasus pada 33 Provinsi). Jurnal Jebeka Volume 11, 27-31.

\section{Buku}

Draper, N., \& Smith, H. (1992). Analisis Regresi Terapan. Jakarta: PT Gramedia Pustaka Utama.

Kurniawan, R., \& Yuniarto, B. (2016). Analisis Regresi: Dasar dan Penerapannya dengan R. Depok: Prenadamedia Group.

Mankiw, N. (2003). Pengantar Ekonomi. Jakarta: Penerbit Erlangga.

Neter, J., Wasserman, W., \& Kutner, M. H. (1989). Applied Linear Regression Models Second Edition. Boston: IRWIN.

Sembiring, R. (2003). Analisis Regresi Edisi Kedua. Bandung: Penerbit ITB.

Sukirno, S. (2004). Makroekonomi: Teori Pengantar Edisi Ketiga. Jakarta: PT Raja Grafindo Persada.

Todaro, M. P. (2000). Economic Development Seventh Edition. Harlow: Addison-Wesley.

Todaro dan Smith. (2003). Economic Development. Harlow: Addison-Wesley. 